\title{
Victims of Maritime Conflict, Compensation Claims and the Role of the Admiralty Court in the Early Modern Period
}

DOI:

10.1080/2049677X.2017.1311548

\section{Document Version}

Accepted author manuscript

Link to publication record in Manchester Research Explorer

\section{Citation for published version (APA):}

Musa, S. (2017). Victims of Maritime Conflict, Compensation Claims and the Role of the Admiralty Court in the Early Modern Period. Comparative Legal History, 5(1). https://doi.org/10.1080/2049677X.2017.1311548

\section{Published in:}

Comparative Legal History

\section{Citing this paper}

Please note that where the full-text provided on Manchester Research Explorer is the Author Accepted Manuscript or Proof version this may differ from the final Published version. If citing, it is advised that you check and use the publisher's definitive version.

\section{General rights}

Copyright and moral rights for the publications made accessible in the Research Explorer are retained by the authors and/or other copyright owners and it is a condition of accessing publications that users recognise and abide by the legal requirements associated with these rights.

\section{Takedown policy}

If you believe that this document breaches copyright please refer to the University of Manchester's Takedown Procedures [http://man.ac.uk/04Y6Bo] or contact uml.scholarlycommunications@manchester.ac.uk providing relevant details, so we can investigate your claim.

\section{OPEN ACCESS}




\title{
Victims of Maritime Conflict, Compensation Claims and the Role of the Admiralty Court in the Early Modern Period
}

\section{Dr. Shavana Musa*}

\begin{abstract}
Victims of war have existed since time immemorial and in the same vein, so have certain mechanisms for the redress of their injuries. Admiralty courts in early modern Europe are historical platforms in which certain groups of victims of maritime conflict could seek compensation under an international prize jurisdiction, as per the law of nations. This article will briefly introduce the reader to the way in which European countries applied their prize jurisdiction. It will then focus on compensation cases during the Anglo-Dutch Wars of the seventeenth century to show how admiralties implemented the right to compensation during these conflicts.
\end{abstract}

\section{Keywords:}

Compensation; reparation; admiralty courts; early modern period; privateering; war; peace.

\section{Introduction}

Compensation for victims of war is often seen as a modern idea, one born from the horrors of the early twentieth century. Civil actions for compensation in particular seem to have proliferated after the Great War. But victims of war have existed, in one shape or form, since time immemorial and in the same vein, so have certain mechanisms for the redress of their injuries. Historical admiralty court records show the profound substantive and procedural legal rights that were bestowed upon victims of maritime conflict, quite often seamen and merchants, as well as their families. To begin with, it is important to note that, fundamentally,

Dr. Shavana Musa is a Lecturer in International Law at The University of Manchester, UK: shavana.musa@manchester.ac.uk 
admiralty courts were legal institutions. They dealt with general maritime issues such as salvage, seamen's wages and general disputes. However, admiralty courts had a very prominent role to play in the materialisation of reparation rights during and after war. The practices of admiralty courts also have a lot to tell us about the history of international law, aside from mere theory. They were international law in practice, giving the admiralty court the character of an international court in many ways. More accurately, they were permanent courts in place to deal with all issues relating to prize during times of war, but also national courts applying international laws and shaping these laws in the process.

Cases relating to war fell under the realms of prize. For instance, in war, taking property from the enemy side was good prize if privateers and navy ships adhered to all the (legal and procedural) rules on prize. Particularly from the seventeenth century onwards, privateering became extremely lucrative for both the state and individual privateers alike. It involved the capture of ships, war supplies, valuable property and even, on occasion, those on board as prisoners of war. Many wars from the early modern period saw privateering practices as one of the main tools employed by states to defeat the enemy, whilst making a financial profit in the process. The captures, however, had to be deemed legal.

However, not all captures and injuries done to merchant ships were in fact legal and many innocents could get caught up in the firing line. Those injured unlawfully during war had the possibility of attending a session at an admiralty court to seek restitution of property and/or compensation for injuries. They would have to prove that the capture was illegal via an evidentiary process in place, as in the case of the English Court of Admiralty. The courts could then, upon following established procedures, authorise the restitution of private property back to its former owners or even order monetary compensation. Alternatively, 
admiralties could authorise commissions, or letters of marque, to allow the wronged victim to capture the enemy's goods by way of compensation. Interestingly, victims could also consist of families of those injured.

In practice, many of the successful victims were neutrals, non-belligerents and quite often victims of collateral damage. Whilst captures of enemy property were deemed lawful and therefore not always legally subject to reparation, there may have been instances where even belligerent subjects were successful in their reparation claim, most likely when the Executive would interfere for the purpose of diplomatic relations. If they were not successful, they still had the right to have their claim heard via this established litigation process. Prize law, as applied by these courts, therefore gave injured persons affected by privateering practices the ability to air their grievances at admiralty court sessions and be granted some form of reparation to mend their injury.

The transnational processes that these admiralty courts functioned within meant that every country, including its citizens, could sue in the courts of others, which were all governed by one and the same law, equally known to each other. This was accepted by England and as far as it was concerned, instilled in 'mutual convenience, eternal principles of justice, wise policy and the consent of nations, which had established a system of procedure, a code of law, and a court for the trial of prize. ${ }^{, 1}$ Before delving into the in-depth detail surrounding the ability for individuals to claim reparation for their wartime injury, this article will briefly introduce the reader to the way in which European countries applied their prize jurisdiction and highlight the intertwinement between national courts and international law. It will then focus on

\footnotetext{
${ }^{1}$ Arthur Browne, A Compendious View of the Civil Law, and of the Law of the Admiralty, Being the Substance of a Course of Lectures Read in the University of Dublin: Volume 2 (Butterworth 1802) 22.
} 
compensation cases during the Anglo-Dutch Wars of the seventeenth century to show how admiralties implemented the right to compensation during these conflicts.

\section{An Introduction to Prize Jurisdiction in Europe}

Prize rules stemmed from the maritime laws of Europe and were of an international (and civilian) character. Wartime issues of capture and injury fell within the bracket of prize law, which was distinct from the usual maritime laws and fell under a specific prize jurisdiction. States agreed that prize law would conform to the law of nations. The law of nations, despite being an ambiguous, yet complex term at one and the same, can quite broadly be described as the rules that governed the behaviour and practices of states and the relations between them, as derived from general usages and opinion. This meant that many European states ought to, at least in theory, consistently follow the same prize rules as their European neighbours. And this observance to the law of nations meant states followed the provision of reparation rule too. This was declared by many treaties of that time. However, in reality, a uniform set of principles was not always reflected with a uniform set of practices. Political agendas and national traditions could lead to variations on certain aspects of prize law and more often than not, these variations stemmed from the benefit that the state would gain from either being a dutiful follower of the law of nations, or doing as it pleased. Treaties were a very important source for dealing with disputes at admiralty courts, viewed as a legal source by judges such as Judge Leoline Jenkins - one of the most important admiralty judges in England of the seventeenth century. ${ }^{2}$ Judges also adhered to doctrinal writings, such as that of Grotius, in particular on the right to redress for wartime injury.

\footnotetext{
${ }^{2}$ William Wynne, The Life of Sir Leoline Jenkins, Judge of the High-Court of Admiralty, And Prerogative Court of Canterbury, \&c. Ambassador and Plenipotentiary for the General Peace at Cologn and Nimeguen, And Secretary of State to K. Charles II and a Compleat Series of Letters, from the Beginning to the End of those Two Important Treaties, Vol. 2 (Joseph Downing et al 1724).
} 
Prize jurisdiction in England, during the periods of the seventeenth and eighteenth centuries, fell within the realms of the civil Court of Admiralty. With the Lord High Admiral towering over its adjudication, the Court of Admiralty was unique in character and even before it became a systemized, regulated and commercial court in the seventeenth century, it had a very international flavour about it, grasping the attention of countries from all around Europe. In fact, given the dominance and practices of England in the sphere of warfare, its European counterparts had a vested interest in the way the English Court of Admiralty applied its prize jurisdiction, which saw many foreign ambassadors attending the court, or in some cases foreign nations seeking its advice. It was deemed that the issues relating to prize fell under the law of nations, and excluded the common law. ${ }^{3}$

Before a fully-fledged Court of Admiralty was born, admiralty jurisdiction in general was effected by local courts and under the supervision of the Crown. However, the Crown had a vested interest in admiralty cases, given its intertwinement with foreign affairs. The common law was not sufficient for the resolution of disputes and the predicaments of foreigners and many cases triggered diplomatic headaches for - sometimes quite outrageously - large compensation claims. The necessity for the crown to shield itself from such claims may have in fact contributed to the Court's initiation in later years. ${ }^{4}$

The English Court of Admiralty lay within an international network of admiralty mechanisms for the resolution of disputes existing in the early modern period. ${ }^{5}$ In France, prize jurisdiction had been vested in the Admiral since around 1500 and ordinances existed confirming the

\footnotetext{
${ }^{3}$ Sir William Blackstone, Commentaries on the Laws of England: Book the Third (A. Strahan 1825) Ch. 5; 70.

${ }^{4}$ William Searle Holdsworth, 'The Development of the Law Merchant and its Courts' in Committee of the Association of American Law Schools (ed) Select Essays in Anglo-American Legal History (Little Brown and Company 1907) Vol 1.

${ }^{5}$ For an analysis on the international character of the English Admiralty Court, see Shavana Musa, 'Tides and Tribulations: English Prize Law and the Law of Nations in the Seventeenth Century' (2015) 17 Journal of the History of International Law 47.
} 
separation between the ordinary laws of France and prize jurisdiction. In comparison to England, the French prize system was much more ad-hoc and not as established. The French were however very innovative in creating many consular admiralty tribunals in all of their territories, including that of their allies. This was envied by British seamen who admired the efficiency that these French admiralties had. The adjudication of captures by French subjects were rendered by officials of the Admiralty of the port that prize were brought into. Appeals were made to the port's provincial Parlement. ${ }^{6}$

Between 1627 and 1669, the grand master of navigation took over from the office of the admiral. Generally, this role had been taken on by key figures such as Richelieu, Anne of Austria and Duc of Vendome. However, all of these people were occupied with other matters and not especially suited for the position of grand master of navigation. Thus, in 1659, by virtue of letters of patent, the conseil des prises was created to initiate upon the start of every war. Appeals were diverted to the Royal Council. ${ }^{7}$

Unlike in England, there was no unified governmental system in the Dutch Republic. Power was derived from the provincial states and municipalities. Here the States General had authority over the Admiralties in the entire period between 1597 and 1795, even during the stadholderless periods. In 1658, we see the States General affirming that

all the affairs touching prizes and merchandises, which are brought into the ports of this state, and demanded by their owners, acknowledge no other judicature and jurisdiction, than those of the respective admiralties privately, and it is before them,

\footnotetext{
${ }^{6}$ Georges Feron, Des Tribunaux de Prises, Organisation, Competence, Procedure (These de Doctorat: Pedone 1896); Auguste Dumas, Etude Sur le Jugement des Prises Maritimes en France Jusqu'a la Suppression de L'office D'amiral (1627) (E Larose 1908); Domenico Alberto Azuni, The Maritime Law of Europe: Volume 2 (G Forman 1806) 262; Helen Josephine Crump, Colonial Admiralty Jurisdiction in the Seventeenth Century (Royal Empire Society 1931).

${ }^{7}$ Carl J. Kulsrud, Maritime Neutrality to 1780: A History of the Main Principles Governing Neutrality and Belligerency to 1780 (The Lawbook Exchange Ltd 2000) 19-20.
} 
that according to the placards, affairs of this kind, with all circumstances concerning the same, must be discussed and decided, as is usual in all other countries in Europe. ${ }^{8}$

In Spain, prizes were determined by intendents or their sub-delegates in the ports that the prizes were carried. And if these were not there, then the intendent of the province. ${ }^{9}$ Appeals were dealt by the council of war. However in 1675, a huge conflict occurred between the Council of War and the province Arragon on the matter of who had exclusive jurisdiction of prizes. The Queen Regent Mother of Charles II, after deliberations with the States General decided that 'the council of war has the exclusive cognizance of all disputes relating to war, as the sending of dispatches, questions relating to war, as the sending of the dispatches, questions relative to salutes and to prizes, which must be determined according to the military laws. 10

All of these admiralty mechanisms in these European states allowed for the dispute resolution of individuals affected by war, including foreign victims not subject of that state. Whilst this section has merely provided a brief description of the mechanisms, it is to highlight the transnational network in which they lay to provide an effective platform for dispute resolution across borders. The resolution could by all means include compensation claims allowing both monetary compensation and restitution of illegally captured property. The following section provides insight into specific cases of war damage stemming from the Anglo-Dutch Wars and how those affected could resort to admiralty courts to seek compensation.

\section{Compensation at Admiralty Courts during the Anglo-Dutch Wars}

\footnotetext{
8 'Resolution of the States General in Answer to Resident Downing's last Memorial of the Same Date', 2 November 1658, vol. 1xi, 357 in Thomas Birch (ed) 'State Papers, 1658: October: A Collection of the State Papers of John Thurloe, Volume 7, March 1658 - May 1660, (Fletcher Gyles 1742) 447-461.

${ }^{9}$ Francis Deak and Philip C. Jessup, 'Early Prize Court Procedure: Part One' (1934) 82(7) University of Pennsylvania Law Review 677, 680; John Francis Bosher, Men and Ships in the Canada Trade: 1660-1760 (National Historic Sites 1992)

${ }^{10}$ Domenico Alberto Azuni, The Maritime Law of Europe: Volume 2 (G Forman 1806) 264
} 
The Anglo-Dutch Wars of the seventeenth were a set of maritime wars that played enormous havoc to the lives of ordinary merchants, seamen and their families - so much so that the number of cases of war victims brought to the Court of Admiralty during these wars increased dramatically. This is likely a reflection of the astounding increase in the number of prizes that had been seized during the wars as well. Lunsford states that during the First and Second Anglo-Dutch Wars, privateers from Zeeland alone had captured prizes to the value of $f 3.5$ million. ${ }^{11}$ The role of these courts to show how injured individuals could in fact obtain compensation is therefore imperative. The Admiralty's jurisdiction in dealing with reparations was applicable during the wars, but was also additional to any reparation provisions that were provided by the treaties ending the wars, namely, the Treaty of Westminster $1654^{12}$, the Treaty of Breda, $1667^{13}$ and the Treaty of Westminster $1674^{14}$.

In April 1649, a statute was enacted ${ }^{15}$ in England declaring the grounds and causes of good prize. Its contents placed a duty on the Court of Admiralty to act justly; it set out what lawful prize should be and the authority of the Council of State to give licence for letters of marque. One particular provision allowed for the restitution of ships to 'the well-affected retaken from the Enemy'. ${ }^{16}$ This clause stated that:

(...) if any prize or prizes so taken, or any part thereof, shall appear and be proved in the said Court of Admiralty, to be any ship or goods belonging to any of the wellaffected and good people of England or of Ireland, remaining and continuing under the protection of the Parliament, and before taken or surprised from them by any Enemy or Rebel, or disaffected person, and afterwards again surprised and retaken by any of

\footnotetext{
${ }^{11}$ Virginia Lunsford, Piracy and Privateering in the Golden Age Netherlands (Springer 2005) 17.

12 Treaty between Great Britain and the Netherlands, signed at Westminster, 5 April 1654, 3 CTS 225.

${ }^{13}$ Treaty between Great Britain and The Netherlands, signed at Breda, 31 July 1667, 10 CTS 255.

${ }^{14}$ Treaty of Peace between Great Britain and The Netherlands, signed at Westminster, 19 February 1674,13 CTS 123.

${ }^{15}$ CH Firth, RS Rait, (eds), 'April 1649: An Act Declaring the Grounds and Causes of Making Prize the Ships and Goods that shall be taken from time to time by the Parliament Ships at Sea, and for the Encouragement of Officers, Mariners and Seamen' in Acts and Ordinances of the Interregnum, 1642-1660 (His Majesty's Stationary Office 1911) 66-75.

${ }^{16}$ ibid
} 
the Fleet or Ships imployed or to be imployed in the service of the Parliament (...) shall be adjudged to be restored. ${ }^{17}$

Only subjects of England and Ireland whose ship or property had been retaken from the enemy could claim restitution of their property at the Court of Admiralty. ${ }^{18}$ An English privateer could not seize English property. For our purposes, focus lays specifically with the prize division, which had the competence to deal with compensation via a commission issued by the Crown and Parliament. Despite the intense conflicts and competition besieging the court system of England during the seventeenth century, common law writs of prohibition, which challenged the admiralty jurisdiction, affected only the ordinary jurisdiction of the Court. The prize jurisdiction of the Court, usually exercised in time of war only, was not, to a large extent, affected. ${ }^{19}$

As mentioned, the admiralty court functioned in addition to any treaty provisions. Whilst an amnesty clause in a treaty prevented claims for restitution and damages, it did not preclude claims of wartime injury to be submitted at an admiralty court where prize law dictated that captures could be brought into these courts and those aggrieved could argue against the capture. Since the resolution of reparation cases affected the peace between England and the Dutch Republic, the Council of State would quite often correspond with Admiralty judges or commissioners of prizes, giving their opinion - occasionally verging on instructions - on the provision of reparations to be made to Dutch subjects. On 24 August 1654, President Laurence of the Council of Whitehall made a statement ordering the release of the Dutch ships the King Solomon of Schiedam, Peace of Amsterdam ${ }^{20}$, Nicholas Cornelissen Koeyen and James Nicholas Coper, along with the ship's goods. The ships had been taken at sea by

\footnotetext{
${ }^{17} \mathrm{ibid}$

${ }^{18}$ ibid

${ }^{19}$ See James Oldham, English Common Law in the Age of Mansfield (University of North Carolina Press 2005) 180, where Oldham refers to Lord Mansfield's observations of his in the case of Lindo v Rodney (1781).

${ }^{20}$ Verbael gehouden, 553.
} 
Constant-Warwick Frigat and brought into Plymouth. ${ }^{21}$ The decision had been prompted by papers from the States General urging compensation and stating that the captures had in fact been unlawful during the war. Restitution was granted and the ships were released.

Tobias Sollicoffer was a merchant whose ship was seized during the First Anglo-Dutch War. An English Captain Eustace Smith, of the Richard and Martha had captured Sollicoffer's ship, the Peter in December of 1653. Tobias Sollicoffer was the subject of the Protestant Canton of Switzerland. His ship carried currants bought in Toulon by himself and a relative, David Sollicoffer. The ship was captured whilst on its way back from Zante. ${ }^{22}$ Following Sollicoffer's petition at the Court of Admiralty, the Commissioners for Prize Goods made a request on 10 March 1655 to view copies of the petition of Sollicoffer. On 27 June 1655, after the commissioners certified the claim and made a report, the case was referred to the Council of State, specifically to Sir Gilbert Pickering, William Sydenham and Edward Montagu. ${ }^{23}$ Thereafter, on 10 July 1655, the Committee of the Council met to discuss the case, in particular, to clarify all details of the incident, such as information about the vessel seized, the extent of damage that had occurred and most importantly, how the amount of compensation should be calculated. ${ }^{24}$

Both restitution and compensation would be given since the shipowner was not Dutch, but a neutral. The difficulty came when deciding on the amount of compensation. The ship had been laden with currants when it was seized. Due to the perishable nature of the currants, they

\footnotetext{
21 'No 121. Fryday 18 August 1654' Verbael gehouden, 550

${ }^{22}$ The records only mention David Sollicoffer once and it is not entirely clear who this person was. It is assumed that they are related in some way, given that they both have the same surname.

23 'June 27. Council. Day's I' in Mary Anne Everett Green (ed), Calendar of State Papers Domestic Series, 1655 Preserved in the State Paper Department of Her Majesty's Public Record Office (Longmans \& Co 1881) SP $18 / 98$.

24 'Committee of the Council on Tobias Sollicoffer's petition' in Mary Anne Everett Green (ed), Calendar of State Papers, Domestic Series, [Commonwealth] 1649-1660 Preserved in the State Paper Department of Her Majesty's Public Record Office: Volume 8, Jan-Oct 1655 (Longman \& Co 1881) SP 18/111 f.61.
} 
were sold off quite quickly prior to the case being called up by the commissioners of prizes. During that period, foreign goods were subject to more duty on goods, as compared to domestic goods. In fact, foreigners paid double what Englishmen were required to pay and since the sale of the currants involved such foreign goods, it was decided on 2 August that the Customs Commissioner and "those interested in the said goods" ${ }^{25}$ should repay Sollicoffer 375l. Financial documentation shows that money relating to the duty owed to Sollicoffer for his loss was paid into the Treasury. Later, a warrant was given to start the process of payment from the Exchequer. ${ }^{26}$ In addition, on 24 July 1655, an Order was also made by the Council for $15,000 \mathrm{l}$ of money to be "collected for the Savoy Protestants' ${ }^{27}$ to be sent to Geneva and Switzerland and for the previous Committee of Council to inform and advise the Committee subsequently tasked to deal with its collection and realisation. ${ }^{28}$

The Sollicoffer case indicates another issue on how victims during the Anglo-Dutch Wars were eligible for reparation. As well as subjects from the warring parties, victims to privateering during the First Anglo-Dutch war could include those from neutral countries. Although the capture of neutral ships was not allowed during war, the huge number of maritime captures at sea during this time resulted in injuries to neutral merchants. Sometimes privateers would use the pretext of war to commit depredations against these neutral ships for good prize, at other times neutral ships would violate neutrality principles by performing belligerent practices, prompting their capture. For example, a ship and its cargo may be contaminated by enemy goods, as per the concept of hostile infection. But there would also be times where the capture of neutral ships was unintentional, perhaps as a case of mistaken

\footnotetext{
25 'July 24' in Mary Anne Everett Green (ed), Calendar of State Papers Domestic Series, 1655 Preserved in the State Paper Department of Her Majesty's Public Record Office (Longmans \& Co 1881) SP 18/99.

26 ibid

${ }^{27}$ This particular entry does not specifically refer to the Sollicoffers or Laurence, but since no other reference to Protestant Cantons was made, other than that to the aforementioned, it is inferred that the $15,000 l$ assigned by the Committee was indeed for them.

${ }^{28}$ ibid
} 
identity through the lack of identification proving neutral status. All these situations triggered cases at the Court of Admiralty, where subjects of neutral countries would attend the English Court to obtain restitution or compensation for their injuries. The protection of neutral interests would rest with the admiralty court, even though it was in the country of the captor seeking the declaration of good prize.

In the first few months of the First Anglo-Dutch War, three ships of neutral status became entangled in the conflict. Firstly, an English Captain called Captain Stoakes seized two ships, the Christiana and the Northcoping, which belonged to a Swedish director, Henry Caarlof, of the Swedish African company. The ships were brought into Plymouth in September 1652. Along with the ships, Stoakes seized the papers, ladings and valuables such as gold, bracelets, chains, hatbands and other rarities. ${ }^{29}$ The captain also decided to personally keep some of the items without authenticating them at the Court of Admiralty. ${ }^{30}$ Henry Caarlof submitted a petition against these actions to the Council of State in January $1653 .{ }^{31}$ In his petition, he included details of another ship, the Stockholm-slott. A private man-of-war had also seized this ship. Henry Caarlof and his ships were detained in Plymouth for four months after the seizures. During this time, he was forced to remain in Plymouth at his own expense. His crew had already begun abandoning him.

Harald Appelboom, a Swedish minister resident at the States-General at the time, wrote on behalf of the Swedish Queen, to the English Parliament. The correspondence expressed

\footnotetext{
${ }^{29}$ Thomas Birch (ed), A Collection of the State Papers of John Thurloe, Esp, Secretary, First, to the Council of State, and Afterwards to the Two Protectors, Oliver and Richard Cromwell, Volume I (Woodward and Davis 1742) 222. In addition to these items, obscurities such as elephant teeth were also taken.

${ }^{30}$ Specifically, Stoakes took Caarloff's great trunk; all the apparel therein; 16 or 18 marks of gold; one box of hatbands; bracelets; chains; rings of gold and Caarloff's chest of linen.

${ }^{31}$ See 'A schedule of the petitioner's present claim, on the behalf of her majesty of Sweden, and the privileged Swedish African company, concerning the two ships the Christiana and Northcoping, taken the $7^{\text {th }}$ September 1652' in A Collection of the State Papers of John Thurloe, Esq. Secretary, First, to the Council of State, and Afterwards to the Two Protectors, Oliver and Richard Cromwell (Thomas Woodward 1742) Vol. I, 222 (thereafter 'State Papers of John Thurloe').
} 
disdain towards the seizures. Caarlof, and other neutral merchants involved in similar circumstances, were at a loss due to English depredations against subjects of a State that was on friendly terms with England at the time. Appelboom first pleaded for the reparation of the Stockholm-slott. He further requested that all the mariners of the ship be redressed for the damage and hardship inflicted upon them. Additionally, he demanded that restitution be granted for all ships seized in this manner, including the two other ships belonging to Caarlof. ${ }^{32}$ Appelboom went onto contend that:

(...) if the amity can by no means be kept between the private persons, except it be mutually maintained by deeds answerable to the sincerity of words respectively given on both sides; much less can it subsist between whole kingdoms and states, if too much shaken by so rude proceedings, and by continual series made altogether intolerable. ${ }^{33}$

Appelboom's outrage on behalf of the Swedish State is apparent. But of further importance is the emphasis on the private person and its relationship with the State. Appelboom's letter shows that the private person was not neglected during times of war, even in the seventeenth century. Whilst the individual could be marginalised and subject to depredations lawfully if explicitly agreed to by countries involved, 'as mutually maintained by deeds answerable to the sincerity of words respectively given on both side, ${ }^{34}$ without reciprocal agreements or lawful authorisation, they could not. Whilst this indicates the way the State was developing and the position of the individual, it also strongly suggests that neutrality as an institution was respected. Violations of such would, even in the seventeenth century, be subject to the breaking of diplomatic ties and calls for reparation, even for the individual.

Subsequent to the correspondence from Appelboom, the English Parliament consulted with the Court of Admiralty on the matter. The Court explained to Parliament that in adjudicating

\footnotetext{
32 'The Swedish Resident in Holland to the Parliament of the Commonwealth of England' in State Papers of John Thurloe, 222-223.

${ }^{33}$ ibid

${ }^{34}$ ibid
} 
the ships, Christiana and Northcoping, alongside the goods that were taken, it was discovered that the property belonged to a person residing in Amsterdam. The resident was a burgher of the enemy and unable to produce letters of safe conduct from the Swedish Majesty. The suspicion surrounding the neutrality and connection to Sweden left the privateers no way of knowing that the ships were not subject to capture. ${ }^{35}$ And consequentially, not subject to any reparations. The Court of Admiralty did however state that whilst Caarlof's case was not eligible for reparation, the English Admiralty did not tolerate the capture of ships and property belonging to subjects of friendly states. Many ships of this nature were restored and owners compensated. The English Parliament conveyed the Admiralty reply to the Swedish Queen.

The case of Caarlof however did not end there. Disputes continued in the Commissioners of the Prize Office. A further remonstrance submitted by Benjamin Bonnell, the resident for the Queen of Sweden in England, to the Council of State protesting against the refusal to restore the gold that was seized in both the ships Christiana and Northcoping. ${ }^{36}$ An order for restitution was thereafter sought on 9 May $1653 .^{37}$

A final answer to the petition of Caarlof shows that the Council of State eventually commanded the State's ships to bring Caarlof into the harbour. They were to hear a statement of the events from the Swedish director himself. After his statement was heard, a final decision was made. The Council declared that they would do what 'correspond[ed] to the

\footnotetext{
35 'The Parliament of the Commonwealth of England to the Queen of Sweden' in State Papers of John Thurloe, 223-224.

${ }^{36}$ Calendar of Papers of Sir James Whitelocke Knt., a Judge of the King's Bench from 1624 to 1632, and of his Son Bulstrode Whitelocke One of the Commissioners of the Great Seal of the Commonwealth, and Ambassador to Queen Christina of Sweden, Whitelocke Papers: Volume XIII Ref S/M (Microform Academic Publishers) para. 32.

${ }^{37} \mathrm{ibid}$
} 
amity they hold with Sweden'. ${ }^{38}$ Despite not fulfilling the evidentiary requirements of the Admiralty to provide proof of belonging to a friendly state, political interferences and diplomatic communication between England and Sweden resulted in Executive interference into the Admiralty's judicial matters. Restitution of the ships was ordered. Given that the gold had first been, quite swiftly, taken to the Tower of London for 'safe custody' and the Commissioners had expressed their hesitation in releasing it, it is very unlikely that the gold was ever returned to its rightful owners.

Whilst the Court of Admiralty in many cases provided reparation to merchants and seamen, not all claimants were successful. Admiralty legal procedure, particularly evidentiary issues, was one of many factors that sometimes prevented a positive outcome in a case. One English merchant, John Paige, observed and experienced the injuries of the war, the impact it had on the trading profession, as well as the lack of faith he had in the admiralty system. Speaking during the war, he stated that ' $[\mathrm{b}]$ oth masters and seamen are much altered within this 6 months; having much encouragement in the [s]tate's service [and] care not for merchant voyages'. ${ }^{39}$ Paige's case is an example where the Court did not allow any redress for his losses during the First Anglo-Dutch War.

John Paige's core expertise of trade was the importation of wine, which was quite firmly established within the Canary trade of the mid-seventeenth century. In addition, Paige was also a merchant of the East India Company and quite often dealt with commodities other than wine, such as sugar and fish. ${ }^{40}$ As an example, two of his ships, The Golden Star and The

\footnotetext{
${ }^{38}$ Mary Anne Everett Green (ed), Calendar of State Papers Domestic Interregnum, 1652-3 (1878) 75-136, para 19.

${ }^{39}$ GF Steckley (ed), 'Letters: to Gowen Paynter and William Clerke, 12 March 1653' in ibid, 82-99, 71c (thereafter 'Steckley, "Letters"').

${ }^{40}$ GF Steckley (ed), 'Introduction' in The Letters of John Paige, London Merchant, 1648-58 (London Record Society 1984) 21.
} 
Elizabeth and John were captured during the war. The fear of capture leads us to believe that Paige was a crestfallen character, whose overwhelming desires towards ownership of vessels turned into a habit of simply freighting them. ${ }^{41}$ This was also due, in part, to his lack of faith in the available legal remedies available for merchant losses during the war. In reacting to the seizure of The Golden Star by a Dutch man-of-war, Paige believed that reparation was an aspiration and not a reality: "No remedy but patience. This is the fruit of our unhappy war $(\ldots)^{42}$.

Paige's perception of the injustice of the law was never more evident than in the case of one of his employer's ships, which the Dutch had subsequently burnt. Having taken the ship to the Admiralty Court to prove his loss, two witnesses whom he had brought in to aid him in his claim, provided false statements about the nature of the ship. The Court did not legitimise the statements and it was not clear whether the false statements had been made maliciously. $\mathrm{He}$ was not able to recover any money for his losses. He later stated: 'though it be law, I am sure it's not equity'. ${ }^{43}$ Whilst Paige felt disheartened by the Admiralty system, other members of society felt that it gave every private person 'a potential voice and liberty to act as he pleases, however unbecoming or unreasonable it may be'. ${ }^{44}$ This indicates a more promising postconflict environment, placing the Court of Admiralty in England as a significant platform for the implementation of reparation rights.

\footnotetext{
${ }^{41}$ C. $105 / 12$, Paynter to Clerke, 13 July and 25 August 1656, ns.

42 Steckley, 'Letters' 72.

${ }^{43}$ ibid, 78a.

${ }^{44}$ ibid, para 178. Oddly enough, one case that at this time had caught the attention of many lawyers and led to these kinds of affirmations was one involving a London merchant, Ricaut. He had been brazenly maintaining that wool - which had been released by the Admiralty Court, given that it had been proved to belong to the King of Spain - was his and that the King of Spain did in fact owe him money: money which was in fact higher in amount than the wool itself. This was a very serious case and the claims were even deemed legitimate, although the eventual outcome is not known. Even so, much excitement was caused as a result of this case and many feared that this would even open the floodgates for individuals to sue a head of state in this way.
} 
In comparison to Britain, the Dutch Republic had a differently organised state structure. The admiralty reflected the disparity within the political and legal framework of the Dutch Republic and was divided into boards. ${ }^{45}$ In fact, it had five admiralty boards that lay in five of the different municipalities to deal with prize related matters. They included the admiralty board for South Holland or the Maas, which rested at Rotterdam; the board for Zeeland at Middelburg; the board for North Holland at Amsterdam; the board at Hoorn or Enkhuizen for West Friesland (or otherwise known as the North Quarter); and the board at Dokhum, and then Harlingen in 1645, sitting for Friesland. ${ }^{46}$ Seven commissioners sat on the boards, with the highest officers appointed by the States General and more junior ones appointed by the admiralty boards themselves. The Admiral, or the Vice Admiral in his place, also had the power to sit at every one of them, but it was in fact the States General that was responsible for the entire supervision of the admiralties. ${ }^{47}$ Since coordination was weak amongst the admiralty boards, meetings at The Hague known as Haagsche Besognes attempted to facilitate supervision, most prominent after $1648 .^{48}$

The financial functioning of the Dutch admiralties posed a problem to the payment of reparation after war. In England, parliamentary supremacy meant financial autonomy, in which funds could be borrowed and profits allocated whenever needed, with the only restrictions deriving from government. In the Dutch Republic, the political makeup made claims processes difficult. However, it was not uncommon for injured individuals to make

\footnotetext{
${ }^{45}$ The Chambers have also been referred to as 'Boards', see Samuel Rawson Gardiner (ed), Letters and Papers Relating to the First Dutch War 1652-1654: Vol I (Printed for the Navy Records Society 1899) 48ff.

${ }^{46}$ A New Description of Holland And the Rest of the United Provinces in General containing Their Government, Laws, Religion, Policy, and Strength; Their Customs, Manners, and Riches; Their Trade to the Indies, \& c. Their Fishery and Bank, with a Particular Account of Amsterdam, Hague, Roterdam, and the other Principal Cities of Holland (H Rhodes 1701) 77. Also see Gardiner, Letters and Papers, Vol. I, 55. Also See Marjolein C 't Hart, The Making of a Bourgeois State: War, Politics and Finance During the Dutch Revolt (Manchester University Press 1993) 39.

${ }^{47}$ Gardiner, Letters and Papers, 57; 389-391.

${ }^{48}$ Marjolein C ' $t$ Hart, The Making of a Bourgeois State: War, Politics and Finance During the Dutch Revolt (Manchester University Press 1993) 41.
} 
claims at these Dutch admiralties and be granted reparations. After the start of the Third Anglo-Dutch War on 2 September 1672, a commission, or Commissie van Retorsie ${ }^{49}$, was authorised by the States-General to a Dordrecht seaman for injuries sustained on account of English and French attacks. The commission stated:

Thus the Kings of France and Great Britain have (...) [attacked and injured] these provinces, as well as good inhabitants everywhere. So is it that the (...) States-General of the United Netherlands, with God's blessing, have found it necessary because of this, so as to obtain reparations for the damage suffered by the aforementioned inhabitants, as well as to prevent as much as is feasible the great ruin of the commerce and navigation [of the Dutch Republic], and to this end, employ all means of retaliation (...) have conceded that Jan Adriaense Noot, (...) Shipper from Dordrecht (...) may attack and capture (...) all ships, and goods belonging to the subjects of the said Kings, and their (...) allies (...) as well as persons (...) in those territories and allegiances $(\ldots){ }^{50}$

These commissions were not as frequently granted as merchants hoped. A pamphlet from the second Anglo-Dutch War suggests that the admiralty of Zeeland had ceased issuing commissions. Many Zeeland privateers complained to the States General. They required reparation for injuries done to them by the 'scoundrel' English who were taking 'bread out of [their] mouths'. Commissions were thus seen as a self-help means of obtaining reparation during these wars and could allow aggrieved merchants to be compensated via good prize, subsequently affirmed at the Dutch admiralty courts. ${ }^{51}$

Compensation claims from the Anglo-Dutch Wars show that the usual claimants at both the English and Dutch admiralties during and after these wars were those with neutral status. In many cases however, these neutrals were not really neutral and had lost their neutral status due to belligerent-type acts. In these situations, it was deemed that they were belligerent. However, even in cases where neutrals had acted as a belligerent, admiralty judges could still

\footnotetext{
${ }^{49}$ They were referred in the Dutch Republic as Commissie van Retorsie.

50 'Commissie van retorsie voor een Deulsche schiper', 2 September 1672, ARA, AA, Verz. Bisdom, 107. Also see Virginia West Lunsford, Piracy and Privateering in the Golden Age Netherlands (Palgrave Macmillan 2005) 18.

${ }^{51}$ ibid 32.
} 
rule in their favour and order restitution or compensation, such as English merchants with Dutch residency trading for the Dutch side in places such as Rotterdam. There were of course authentic neutrals whose injuries would be redressed, as well as other successful reparation cases where the evidence pointed in the favour of the claimants or where political interest pointed towards redress. Whilst one will notice the legal procedures and cases of compensation, it is also interesting to observe the distinct procedural differences between the English Admiralty in comparison to the Dutch, despite both following the 'law of nations'.

\section{Bond and Bail}

Whilst prize law itself was at the cornerstone of how admiralty judges ruled on reparation cases, of importance is how admiralty courts, in practice, financed reparation claims. Though the national budget was an option and sometimes provided funds for victims of war, the admiralty courts success in paying damages to victims can also be attributed to the bond and bail mechanism. Bond and bail placed a procedural obligation on all captors wishing to partake in privateering during war. It involved the payment of money into the admiralty court by way of security, usually by respectable guarantors selected by the privateer. Sometimes they would be the ship owners, the captain, book-keepers, or even an individual not related to the business of privateering at all, but merely with a relation to the commander.

In England, the provision of bond money had been in existence since the fifteenth century and could vary depending on the size of the ship. Should the privateer act in violation of prize law and capture the goods of innocent persons, that money could be forfeited and/or awarded as damages to the injured party. It was a way of ensuring good conduct on part of the privateering commander and his crew. Most admiralty courts necessitated the giving of bail money, which had been a long established, consistent practice outlined by the rules governing 
privateering. All types of privateers were instructed to follow these prior to the initiation of armed conflict. This practice was more explicitly affirmed and formalized during the period of the seventeenth century, when sea-wars, such as the Anglo-Dutch wars, and competition for global trade was most prominent. The Treaty of Westminster of 1654 declared the pre requisite act of giving security before commissions were granted and the commercial treaty between England and the Netherlands in $1668^{52}$ stated that security was to be given before execution of a sentence. Article 10 of a commercial treaty between France and England ${ }^{53}$ also placed the obligation on commanders of privateers to provide security for the purposes of any liability that may occur due to their actions. This particular treaty went onto have a separate article pertaining to security notwithstanding any appeal. The Anglo-Dutch Friendship and Navigation Treaty of $1674^{54}$ also stated that bail should be submitted. Thereafter, various treatises explicitly declared the giving of surety as an inherent prize court mechanism:

[B] efore letters of marque or reprizals are issued, it is required that bail be given in the High Court of Admiralty, before the Judge thereof, in the Sum of 30001. if the ship carries about a hundred and fifty Men, and if a lesser Number 15001. to make good any Damages that shall be done contrary to the Intent, and true Meaning of their Instructions, and (in case the whole of the Prizes is not given to the Captors) to cause to be paid to his Majesty, or such Person as shall be authorized to receive the same, the full tenth part of the Prizes, Goods, and Merchandizes, according as the same shall be appraised, as also such Customs as shall be due to the Crown. ${ }^{55}$

Another commission authorised by the office of the Lord High Admiral in 1696 to Peter Fewnis for the ship Mary Rose stated:

Provided always, that before you issue such Commission, Security be given thereupon, according as is directed in Her Late Majesty's Instructions afore mentioned: As also, That a Recognizance or sufficient Bail, not exceeding Five hundred Pounds, be enter'd into, obliging him not to carry in the said Ship more than

\footnotetext{
${ }^{52}$ Treaty of Commerce between Great Britain and The Netherlands, signed on 17 February 1668 at The Hague, 10 CTS 441.

${ }^{53}$ Articles 10 and 13, Treaty of Commerce between France and England, signed on 24 February 1677 at St. Germaine en Layes, 14 CTS 475.

${ }^{54}$ Treaty of Navigation and Commerce between England and The Netherlands, signed at London, 1(10 December 1674, 13 CTS 255.

${ }^{55}$ Josiah Burchett, A Complete History of the most remarkable transactions at sea, from the earliest accounts of time to the conclusion of the last war with France...And in a more particular manner of Great Britain, from the time of the revolution, in the year 1688, to the aforesaid period (WB for J. Walthoe and J. Walthoe, junior, 1720).
} 
one half of her Complement of Seamen (...); and also that he do give Security strictly to confirm himself to the Regulations contained in Their Majesties Proclamation of the Twelfth of July, $1694 .{ }^{56}$

The giving of bail was therefore an existing reparative tool to prevent any misconduct of privateers, but also to compensate for injury that was done in wartime:

without any security whatever having been given for their conduct, which is uniformly required and taken in the most solemn manner from every Privateer (...) noncommissioned vessels would be roving about, committing Acts of Violence and depredation on such ships as they might fall in with (...). ${ }^{57}$

A later draft article declared 'that all persons on either side that shall go out to sea on particular commissions, shall before they take out their commissions, put in good and sufficient security before the Judges of the Court where the commission issues by responsible Men, not of the Ships Company, not to for any injury or wrongh to the people or inhabitants of each other'. These alleviated the risk of potential future reparation claims and allowed the payment of the same should such claims materialize. This admiralty court rule of giving surety was a successful mechanism to ensure good practices on the seas and to limit unlawful wartime injury as much as possible. It adds weight to the importance of the admiralty court's role for the individual victim of war in the early modern period.

\section{Concluding Remarks}

Admiralty courts in Europe in the early modern period allowed individuals injured during war to seek compensation through established transnational legal processes. They were instrumental to the application of international laws at that time, more aptly referred to as the law of nations. Whilst the cases in this article have quite clearly shown the apparent tendency for such victims to constitute neutrals (whether authentic or not), even if compensation was not granted, the process of litigation proved commendable for the purposes of truth-seeking. Nonetheless, there is a slight bitterness to this story of perceived justice when one thinks of

\footnotetext{
${ }^{56}$ National Archives, HCA 25/13.

${ }^{57}$ PRO, HCA 45/12.
} 
the more-than-occasional dominance of diplomatic relations, interests of the state and consequently, the moulding of who the 'victim' should actually be. Furthermore, whilst the workings of admiralty courts in different countries showed the (idealistic) observance to the substantive law of nations, inevitable differences in national procedural rules and political interests made unwavering obedience to the law of nations completely impossible. It is these points that may have interrupted the judicial powers at these courts to justly follow existing rules and procedures on compensation, despite the existence of this permanent compensatory platform. The bond and bail mechanism inherent within these courts do, however, show that compensation potential went beyond merely a right, to actual implementation. This indispensable aspect of the admiralty court, to materialise the right to compensation, proves undeniably valuable for those injured during war. It was not only beneficial for the ius post bellum, but also the ius in bello in its purpose to prevent misconduct through the giving of security. With all this evidence on the wonders of the early modern admiralty court, as precursors to international rules on war and peace today, it begs the question why more research on this has not been done and why the stones of this crucial aspect of the history of international law have been left unturned? 